\title{
Geology and Assessment of Undiscovered Oil and Gas Resources of the Hope Basin Province, 2008
}

Chapter D of

The 2008 Circum-Arctic Resource Appraisal

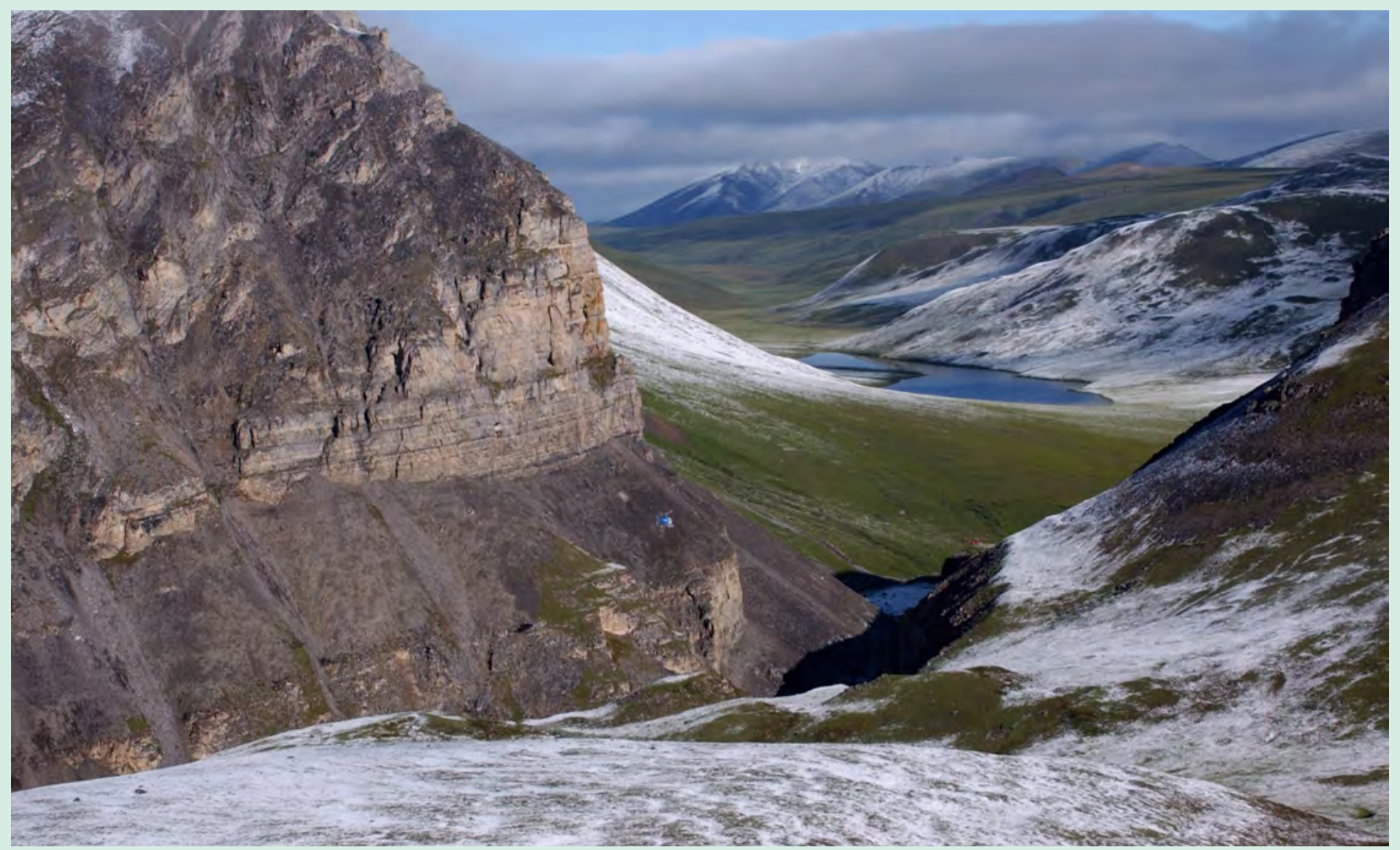

Professional Paper 1824

U.S. Department of the Interior

U.S. Geological Survey 
COVER

Northwestward view across the southern foothills of the Brooks Range along Akmagolik Creek, approximately 150 miles southwest of Prudhoe Bay, Alaska. Exposed rocks are part of the Mississippian-Pennsylvanian Lisburne Group and include a thrust-fault ramp at left. Photo includes two helicopters for scale, a blue-and-white one near the center and a red one at center-right at creek level. U.S. Geological Survey photograph by David Houseknecht. 


\section{Geology and Assessment of Undiscovered Oil and Gas Resources of the Hope Basin Province, 2008}

By Kenneth J. Bird, David W. Houseknecht, and Janet K. Pitman

Chapter D of

The 2008 Circum-Arctic Resource Appraisal

Edited by T.E. Moore and D.L. Gautier

Professional Paper 1824 


\title{
U.S. Department of the Interior RYAN K. ZINKE, Secretary
}

\section{U.S. Geological Survey William H. Werkheiser, Acting Director}

\author{
U.S. Geological Survey, Reston, Virginia: 2017
}

For more information on the USGS — the Federal source for science about the Earth, its natural and living resources, natural hazards, and the environment-visit https://www.usgs.gov or call 1-888-ASK-USGS.

For an overview of USGS information products, including maps, imagery, and publications, visit https://store.usgs.gov.

Any use of trade, firm, or product names is for descriptive purposes only and does not imply endorsement by the U.S. Government.

Although this information product, for the most part, is in the public domain, it also may contain copyrighted materials as noted in the text. Permission to reproduce copyrighted items must be secured from the copyright owner.

Suggested citation:

Bird, K.J., Houseknecht, D.W., and Pitman, J.K., 2017, Geology and assessment of undiscovered oil and gas resources of the Hope Basin Province, 2008, chap. D of Moore, T.E., and Gautier, D.L., eds., The 2008 Circum-Arctic Resource Appraisal: U.S. Geological Survey Professional Paper 1824, 9 p., https://doi.org/10.3133/pp1824D.

ISSN 2330-7102 (online) 


\section{The 2008 Circum-Arctic Resource Appraisal}

\section{Chapters}

A. Introduction to the 2008 Circum-Arctic Resource Appraisal (CARA) Professional Paper By Donald L. Gautier and Thomas E. Moore

B. Methodology for Assessment of Undiscovered Oil and Gas Resources for the 2008 Circum-Arctic Resource Appraisal

By Ronald R. Charpentier

\section{North America}

C. Geology and Assessment of Undiscovered Oil and Gas Resources of the Chukchi Borderland Province, 2008

By Kenneth J. Bird and David W. Houseknecht

D. Geology and Assessment of Undiscovered Oil and Gas Resources of the Hope Basin

Province, 2008

By Kenneth J. Bird, David W. Houseknecht, and Janet K. Pitman

E. Geology and Assessment of Undiscovered Oil and Gas Resources of the Arctic Alaska Petroleum Province, 2008

By David W. Houseknecht, Kenneth J. Bird, and Christopher P. Garrity

F. Geology and Assessment of Undiscovered Oil and Gas Resources of the Yukon Flats Basin Province, 2008

By Kenneth J. Bird and Richard G. Stanley

G. Geology and Assessment of Undiscovered Oil and Gas Resources of the Northwest Canada Interior Basins Province, Arctic Canada, 2008

By Marilyn E. Tennyson and Janet K. Pitman

H. Geology and Assessment of Undiscovered Oil and Gas Resources of the Franklinian Shelf Province, Arctic Canada and North Greenland, 2008

By Marilyn E. Tennyson and Janet K. Pitman

I. Geology and Assessment of Undiscovered Oil and Gas Resources of the Sverdrup Basin Province, Arctic Canada, 2008

By Marilyn E. Tennyson and Janet K. Pitman

\section{Greenland}

J. Geology and Assessment of Undiscovered Oil and Gas Resources of the West GreenlandEast Canada Province, 2008

By Christopher J. Schenk 
K. Geology and Assessment of Undiscovered Oil and Gas Resources of the East Greenland Rift Basins Province, 2008

By Donald L. Gautier

\section{North Atlantic Ocean}

L. Geology and Assessment of Undiscovered Oil and Gas Resources of the Jan Mayen Microcontinent Province, 2008

By Thomas E. Moore and Janet K. Pitman

\section{Eurasia}

M. Geology and Assessment of Undiscovered Oil and Gas Resources of the Mezen' Basin Province, 2008

By Timothy R. Klett and Janet K. Pitman

N. Geology and Assessment of Undiscovered Oil and Gas Resources of the Timan-Pechora Basin Province, Russia, 2008

By Christopher J. Schenk

0. Geology and Assessment of Undiscovered Oil and Gas Resources of the East Barents Basins Province and the Novaya Zemlya Basins and Admiralty Arch Province

By Timothy R. Klett

P. Geology and Assessment of Undiscovered Oil and Gas Resources of the North Kara Basins and Platforms Province, 2008

By Timothy R. Klett and Janet K. Pitman

0. Geology and Assessment of Undiscovered Oil and Gas Resources of the Northern West Siberian Mesozoic Composite Total Petroleum System of the West Siberian Basin Province, Russia, 2008

By Christopher J. Schenk

R. Geology and Assessment of Undiscovered Oil and Gas Resources of the Yenisey-Khatanga Basin Province, 2008

By Timothy R. Klett and Janet K. Pitman

S. Geology and Assessment of Undiscovered Oil and Gas Resources of the Northwest Laptev Sea Shelf Province, 2008

By Timothy R. Klett and Janet K. Pitman

T. Geology and Assessment of Undiscovered Oil and Gas Resources of the Lena-Anabar Basin Province, 2008

By Timothy R. Klett and Janet K. Pitman 
U. Geology and Assessment of Undiscovered Oil and Gas Resources of the Tunguska Basin Province, 2008

By Christopher J. Wandrey and Timothy R. Klett

V. Geology and Assessment of Undiscovered Oil and Gas Resources of the Lena-Vilyui Basin Province, 2008

By Timothy R. Klett and Janet K. Pitman

W. Geology and Assessment of Undiscovered Oil and Gas Resources of the Laptev Sea Shelf Province, 2008

By Timothy R. Klett and Janet K. Pitman

X. Geology and Assessment of Undiscovered Oil and Gas Resources of the Zyryanka Basin Province, 2008

By Timothy R. Klett and Janet K. Pitman

Y. Geology and Assessment of Undiscovered Oil and Gas Resources of the East Siberian Sea Basin Province, 2008

By Kenneth J. Bird, David W. Houseknecht, and Janet K. Pitman

Z. Geology and Assessment of Undiscovered Oil and Gas Resources of the Vilkitskii Basin Province, 2008

By Kenneth J. Bird, David W. Houseknecht, and Janet K. Pitman

AA. Geology and Assessment of Undiscovered Oil and Gas Resources of the Long Strait Province, Russian High Arctic, 2008

By Kenneth J. Bird, David W. Houseknecht, and Janet K. Pitman

\section{Arctic Ocean}

BB. Geology and Assessment of Undiscovered Oil and Gas Resources of the Amerasia Basin Petroleum Province, 2008

By David W. Houseknecht, Kenneth J. Bird, and Christopher P. Garrity

CC. Geology and Assessment of Undiscovered Oil and Gas Resources of the LomonosovMakarov Province, Central Arctic Ocean, 2008

By Thomas E. Moore, Kenneth J. Bird, and Janet K. Pitman

DD. Geology and Assessment of Undiscovered Oil and Gas Resources of the Eurasia Basin Province, Eastern Arctic Ocean, 2008

By Thomas E. Moore and Janet K. Pitman 


\section{Contents}

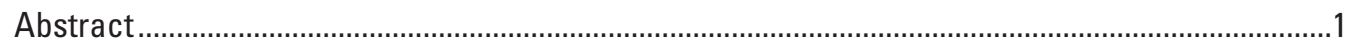

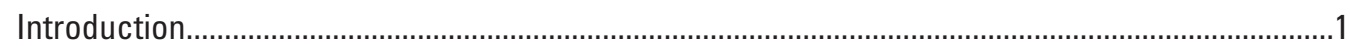

Geologic Setting and Stratigraphy ..........................................................................................

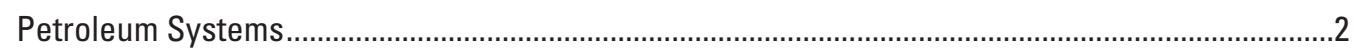

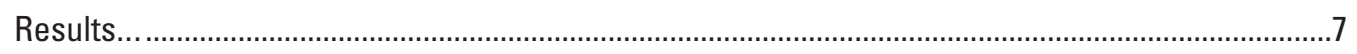

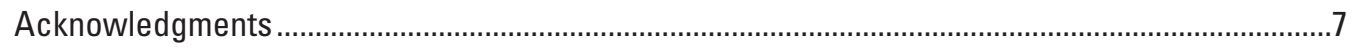

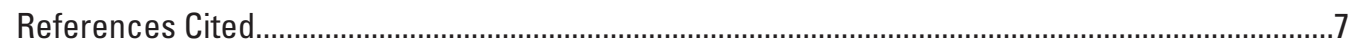

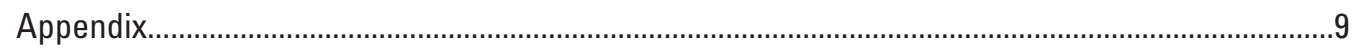

\section{Appendix}

[Available for download at https://doi.org/10.3133/pp1824D]

1. Input data for the Hope Basin Assessment Unit

\section{Figures}

1. Map of Hope Basin, in relation to other sedimentary basins of the East Siberian and Chukchi Seas that lie within and adjacent to the Brooks Range-Chukotka orogen ........................1

2. Maps of Hope Basin and nearby areas, Russian Arctic .............................................................

3. Correlation diagram of subsurface stratigraphic control and thermal maturity for the Hope Basin Province provided by exploratory wells

4. Seismic profile across the Hope Basin, showing characteristic extensional faulting and location of pseudowell used in burial-history analysis .....................................................

5. Burial-history diagrams from a pseudowell located in deepest part of the Hope Basin ...........6

\section{Table}

1. Assessment results for the Hope Basin Province …........................................................... 
Chapter D

\title{
Geology and Assessment of Undiscovered Oil and Gas Resources of the Hope Basin Province, 2008
}

\author{
By Kenneth J. Bird, David W. Houseknecht, and Janet K. Pitman
}

\begin{abstract}
The Hope Basin, an independent petroleum province that lies mostly offshore in the southern Chukchi Sea north of the Chukotka and Seward Peninsulas and south of Wrangel Island, the Herald Arch, and the Lisburne Peninsula, is the largest in a series of postorogenic (successor) basins in the East SiberianChukchi Sea region and the only one with exploratory-well control and extensive seismic coverage.

In spite of the seismic coverage and well data, the petroleum potential of the Hope Basin Province is poorly known. The adequacy of hydrocarbon charge, in combination with uncertainties in source-rock potential and maturation, was the greatest risk in this assessment. A single assessment unit was defined and assessed, resulting in mean estimates of undiscovered, technically recoverable resources that include $\sim 3$ million barrels of oil and 650 billion cubic feet of nonassociated gas.
\end{abstract}

\section{Introduction}

The Hope Basin is the easternmost of six basins situated on the continental shelf of the East Siberian and western Chukchi Seas (fig. 1). The basin is wedge shaped and covers an area of 205,000 $\mathrm{km}^{2}$ that is mostly offshore in the southern part of the Chukchi Sea. The basin extends $\sim 700 \mathrm{~km}$ westward from Kotzebue Sound to just south of Wrangel Island at long $\sim 178^{\circ} \mathrm{W}$., where $<1 \mathrm{~km}$ of sedimentary fill is mapped, and as much as $400 \mathrm{~km}$ northward from Chukotka to the Herald Arch (fig. 2). The Hope Basin is bordered on the northeast by the western Brooks Range, a small segment of the Arctic Alaska fold- and thrust belt, and the Lisburne Hills-Herald Arch, which separates the Hope Basin from the Arctic Alaska Province and the North Chukchi-Wrangel Foreland Province. For the purposes of this assessment, the Hope Basin is designated as both a separate province and an assessment unit (AU), $\sim 5$ percent of which is south of the Arctic Circle (fig.1).

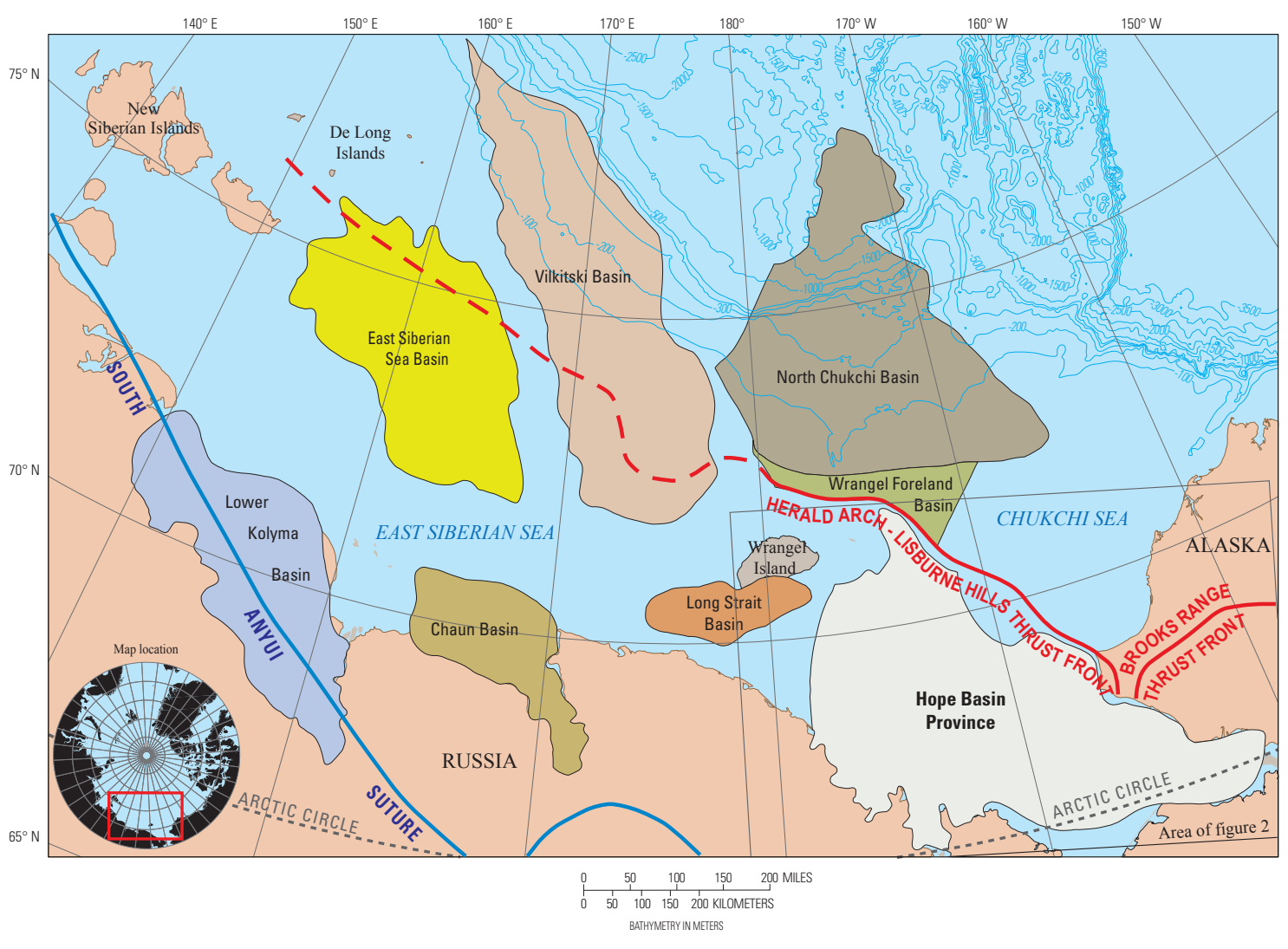

Figure 1. Map of Hope Basin in relation to other sedimentary basins of the East Siberian and Chukchi Seas that lie within and adjacent to the Brooks Range-Chukotka orogen (defined as the area between the South Anyui Suture and the Herald Arch-Frontal Brooks Range thrust). Map created by C.P. Garrity, U.S. Geoogical Survey; basin outlines from Grantz and others (2009). 


\section{Geologic Setting and Stratigraphy}

The Hope Basin is a successor or intermontaine basin that formed on the Brooks Range-Chukotka orogenic belt. The orogenic belt, marking the southern part of the Arctic Alaska microplate, is bounded on the south by the South Anyui Suture and the Kobuk Fault along the south flank of the Brooks Range, and on the north by the Brooks Range-Herald Arch-Lisburne Hills thrust front and its proposed westward extension along the continental shelf to the New Siberian Islands (fig. 1). The South Anyui Suture formed in the Early Cretaceous (Neocomian) (Sokolov and others, 2002), whereas the north thrust boundary may be as old as Aptian and as young as early Paleogene ( 60 Ma) (Moore and others, 2002). Evidence from the Alaska North Slope foreland basin (huge Aptian-Albian sediment volume, relatively fine sediment, and eastward-directed filling of the basin) led Molenaar (1985) to conclude that much more of the orogenic belt than just the relatively narrow Lisburne Hills-Herald Arch-Wrangel Arch was a sediment source area and that the orogenic belt probably included the entire Hope Basin area and beyond (because Hope Basin itself is too young to have been a source for the Colville Basin deposits). Later information indicating that a significant part of the North Chukchi basin fill is of similar age (Grantz and others, 1990; Lothamer, 1994) reinforces this interpretation. Thus, the Hope Basin region was probably a sediment source area throughout most of the Cretaceous. The origin of the basin is uncertain; it has been variously ascribed to strike-slip faulting, orogenic collapse, or escape tectonics (Tolson, 1987; Worrall, 1991; Klemperer and others, 2002; Elswick and Toro, 2003; Scholl and Stevenson, 1989).

Evidence from the only exploratory wells drilled in the basin, which are located in the far southeast (fig. 2) in an area that has been described as a subbasin ("Kotzebue" of most authors or "Selawik" of Decker and others, 1988) separated from the main part of the basin by a west-trending linear basement high (Kotzebue Arch), shows a stratigraphic section composed of a lower sequence of Paleogene volcaniclastic nonmarine sandstone and conglomerate, with tuffs and basalt flows overlain by Neogene coal-bearing nonmarine and possibly marine sandstone and mudstone (Decker and others, 1988; Tolson, 1987; Haimila and others, 1990). In this area, Cenozoic deposits rest unconformably on Paleozoic metasedimentary rocks (fig. 3) similar to metasedimentary rocks widely exposed on the Seward Peninsula (Till and Dumoulin, 1994).

Projection of well control into the grid of publicly available seismic data covering the east half of the Hope Basin shows two or three mappable sequences above acoustic basement (Eittreim and others, 1978; Zerwick, 1998; Elswick and Toro, 2003). Total basin fill locally exceeds $6 \mathrm{~km}$ in thickness (fig. 2). Each sequence generally shows onlap and thinning at the basin margins and thickening toward the basin center. Numerous normal faults with both northward and southward vergence and an overall northwesterly trend characterize the basin (fig. 4). Deeper parts of some faults show fanning (growth) geometry, and many faults extend upward to the seafloor. Whereas the eastern part of the Hope Basin is interpreted as Cenozoic strata on acoustic basement, interpretations of proprietary seismic data in the western part of the basin show significant thicknesses of deformed Mesozoic strata in angular relation beneath Cenozoic strata (for example, Shipilov, 1989; Warren and others, 1995). The age, lithology, and thermal maturity of proposed Mesozoic strata are unknown. These observations suggest that parts of the orogenic belt are relatively more intact and not as highly deformed as observed in surface exposures.

\section{Petroleum Systems}

No petroleum systems have been identified in the Hope Basin Province. Indications of gas on seismic records are rare to nonexistent, but minor hydrocarbon occurrences interpreted as biogenic methane or bitumen derived from terrigenous organic material were documented by Troutman and Stanley (2004) in the Kotzebue Sound area in petroleum-exploration wells, seismic shotholes, and a water well. Demonstrated North Slope petroleum-source rocks (Mississippian coal and deep-marine mudstone and Triassic and Jurassic distal-marine facies) that are exposed in the western Brooks Range and the Lisburne Hills evidently underlie the eastern parts of the Hope Basin (Moore and others, 2002). However, these rocks are thermally mature to overmature for petroleum generation in this area (Johnsson and others, 1999; Moore and others, 2002) and reached maturity before the basin formed. For these reasons, petroleum-source rocks in the Hope Basin Province are limited to nonmarine Cenozoic basin fill and likely consist of coal and carbonaceous mudstone.

Burial history of a pseudowell located in the deepest part of the basin on the seismic profile in figure 4 was modeled to determine thermal maturity and the timing of petroleum generation (fig. 5). This analysis, using a higher initial heat flow coincident with documented volcanism decreasing over time, suggests that the onset of petroleum generation for source rocks at the base of the oldest sequence (unit I) could have occurred below $1.5 \mathrm{~km}$ of burial as early as $40 \mathrm{Ma}$; but as heat flow decreased, petroleum generation for source rocks in the overlying sequence (unit II) would not have occurred until nearly $2.5 \mathrm{~km}$ of burial at $11 \mathrm{Ma}$. No petroleum generation is indicated for source rocks in the uppermost sequence.

AU Description.-The Hope Basin AU encompasses the entire basin, covering an area of $\sim 205,000 \mathrm{~km}^{2}$ (fig. 2). The basin is a postorogenic, successor basin of uncertain origin. Basin fill, which is locally $>6 \mathrm{~km}$ thick, is inferred to consist predominantly of Cenozoic nonmarine sandstone and conglomeratic strata that contain basalt, tuffs, and volcanic clasts in the Paleogene section and sandstone, mudstone, coal, and shallow-marine deposits in the Neogene section. Northwesttrending normal faults are pervasive and have been active at various times throughout the history of the basin; continuing 


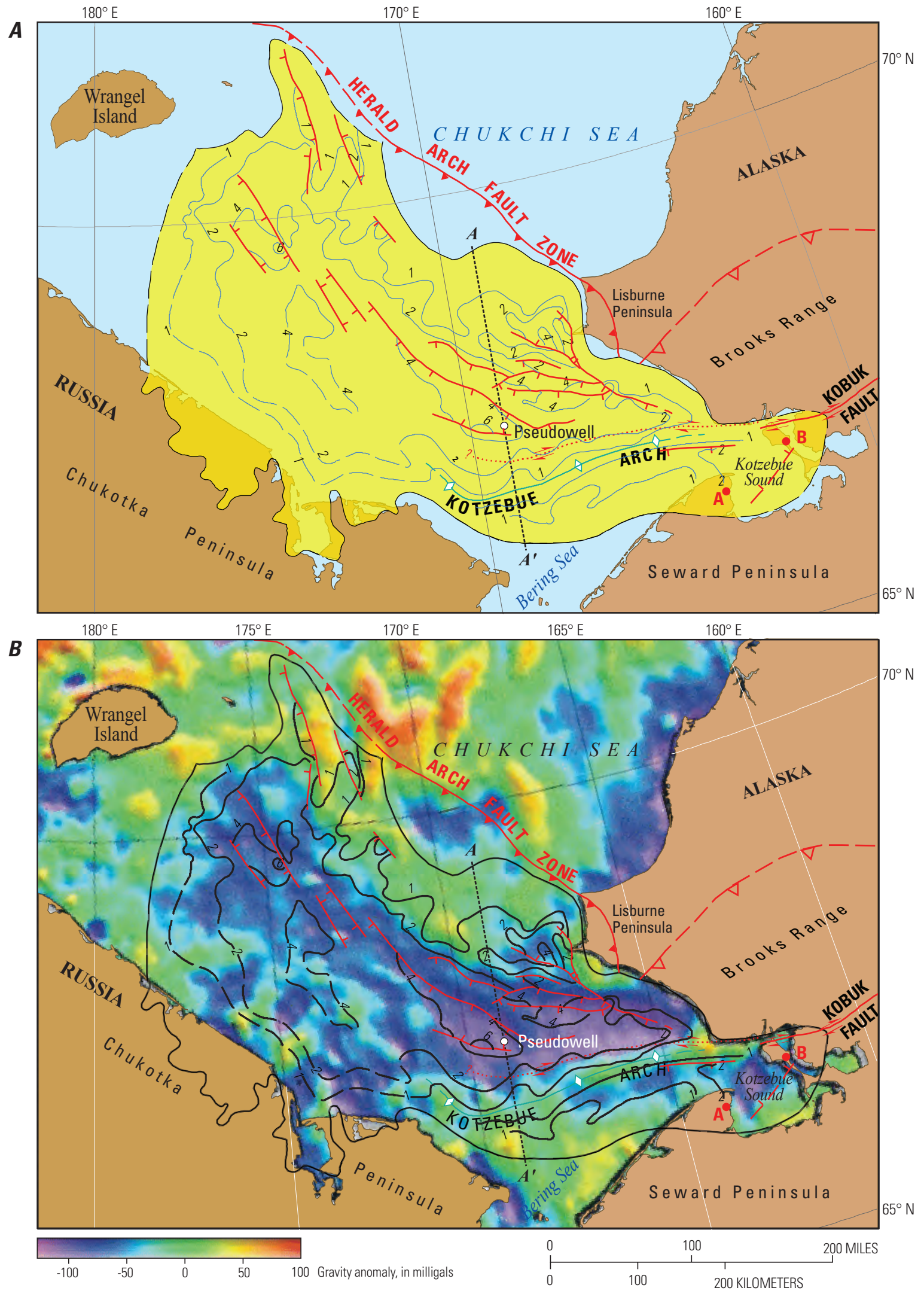

Figure 2. Maps of Hope Basin and nearby areas, Russian Arctic (modified from Grantz and others, 2009). $A$, Basin outline, showing locations of faults, contours of depth to acoustic basement (in kilometers), and locations of exploratory wells (A, Cape Espenberg; $B$, Nimiuk Point), and of pseudowell used in burial-history analysis (see fig. 5). $B$, Same features as in $A$, shown in relation to free-airgravity-anomaly map (modified from Mazarovich and Sokolov, 2003). 


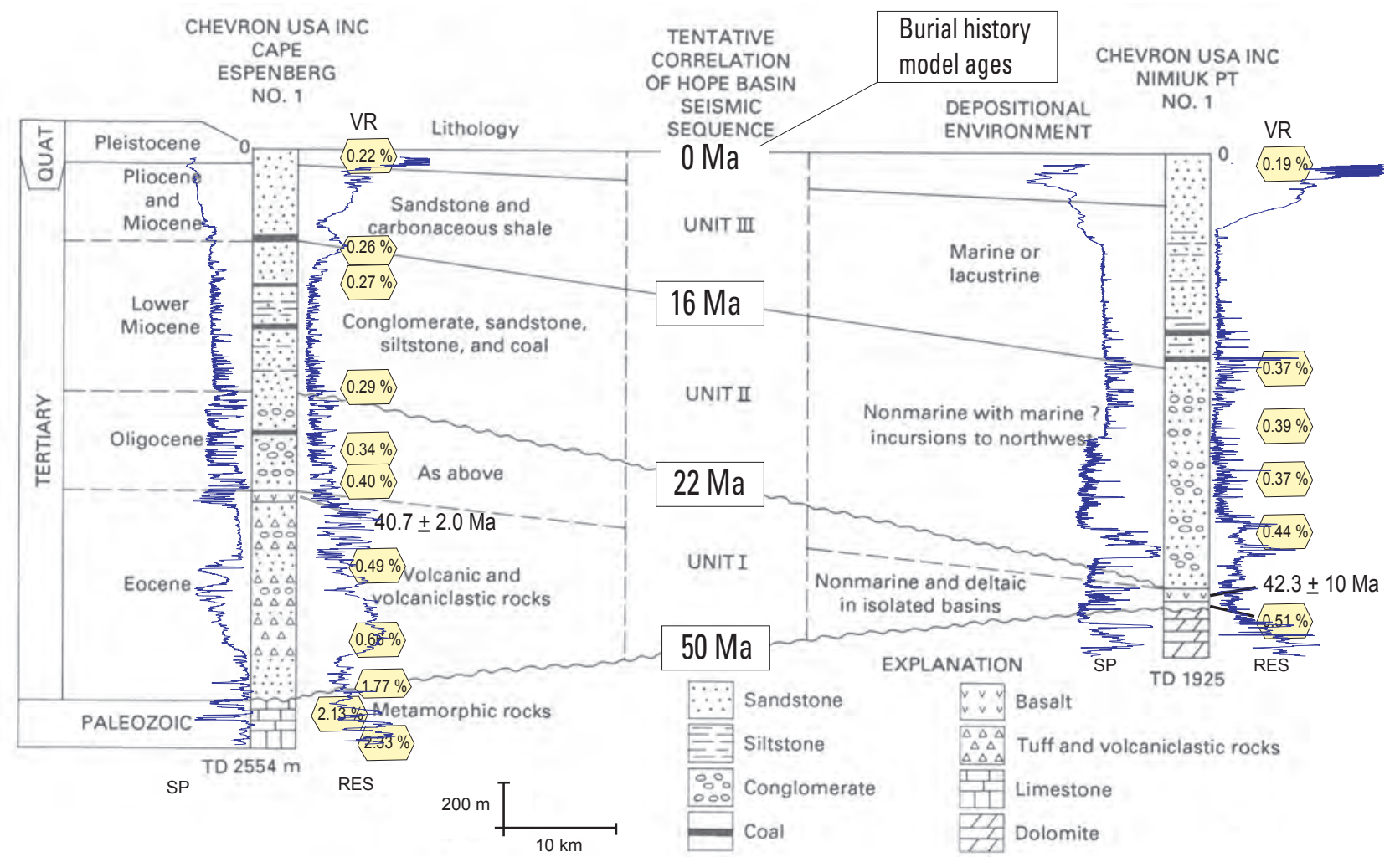

Figure 3. Correlation diagram of subsurface stratigraphic control and thermal maturity for the Hope Basin Province provided by exploratory wells (modified from Haimila and others, 1990). Quat, Quaternary; RES, resistivity; SP, spontaneous potential; TD, total depth of well; VR, vitrinite reflectance in percent (\%). See figure 2 for location of wells. Well data from Alaska Oil and Gas Conservation Commission, Anchorage, Alaska; Vitrinite-reflectance data from Johnsson and others (1999).

seismic activity is indicated by many faults that extend to the seafloor and by recent earthquakes (Fujita and others, 1990).

Petroleum source rocks are postulated to be coal beds and carbonaceous mudstone and so are predominantly gas prone. However, gas indications on seismic records are virtually absent, and those occurrences in wells and shotholes are relatively minor and considered biogenic. Only that part of the basin with $>2.5 \mathrm{~km}$ of fill is estimated to be capable of petroleum generation. Demonstrated North Slope petroleum source rocks of the Brooks Range-Lisburne Peninsula region probably underlie the eastern part of the Hope Basin as part of the acoustic basement, but these rocks evidently are thermally overmature as observed in outcrop.

Geological Analysis of Assessment Unit Probability.Considering data limitations and sparse exploration activity, the probability that the Hope Basin AU contains at least one undiscovered petroleum accumulation $>50$ million barrels of oil equivalent (MMBOE) is considered to be $\sim 0.17$ (17 percent) (appendix 1).

Charge.-A charge probability of 0.3 (30 percent) was assigned to this AU (appendix 1). Source rocks were considered to be coal and carbonaceous mudstone of unknown quality and thickness. Furthermore, the area in which these rocks are thermally mature is limited to that part of the basin where they are buried to depths of $>2.5 \mathrm{~km}$.
Rock.-A rock probability of 0.7 (70 percent) for the adequacy of reservoirs, traps, and seals was assigned to this AU. The best reservoirs are probably present in the Neogene and upper part of the Paleogene section. Volcanic components in the lower Paleogene section likely resulted in greatly diminished reservoir quality. Adequate mudstone and fault seals are considered a significant risk.

Timing and Preservation.-Because the basin is currently at maximum burial and has a history of continuous subsidence, a relatively favorable timing and preservation probability of 0.8 ( 80 percent) for a field larger than the minimum size is assigned to this AU.

Analogs.-The U.S. Geological Survey (USGS) World Analog Database (Charpentier and others, 2008) was searched on coaly source rock, Type III kerogen. This search yielded 24 analog AUs, which were then pared down by eliminating those analog AUs with marine deltaic settings, as well as foreland basins with fold-and-thrust structures, which are inconsistent with the geologic setting of the Hope Basin.

Number of Accumulations. - On the basis of the analog dataset, the total number of petroleum accumulations larger than $50 \mathrm{MMBOE}$ was set to 1,5 , and 40 for the minimum, median, and maximum, respectively.

$\mathrm{Oil} / \mathrm{Gas}$ Ratio.- On the basis of the inferred dominance of gas-prone kerogen in coaly source rocks and the absence of indications of oil-prone source rock, the minimum, median, 


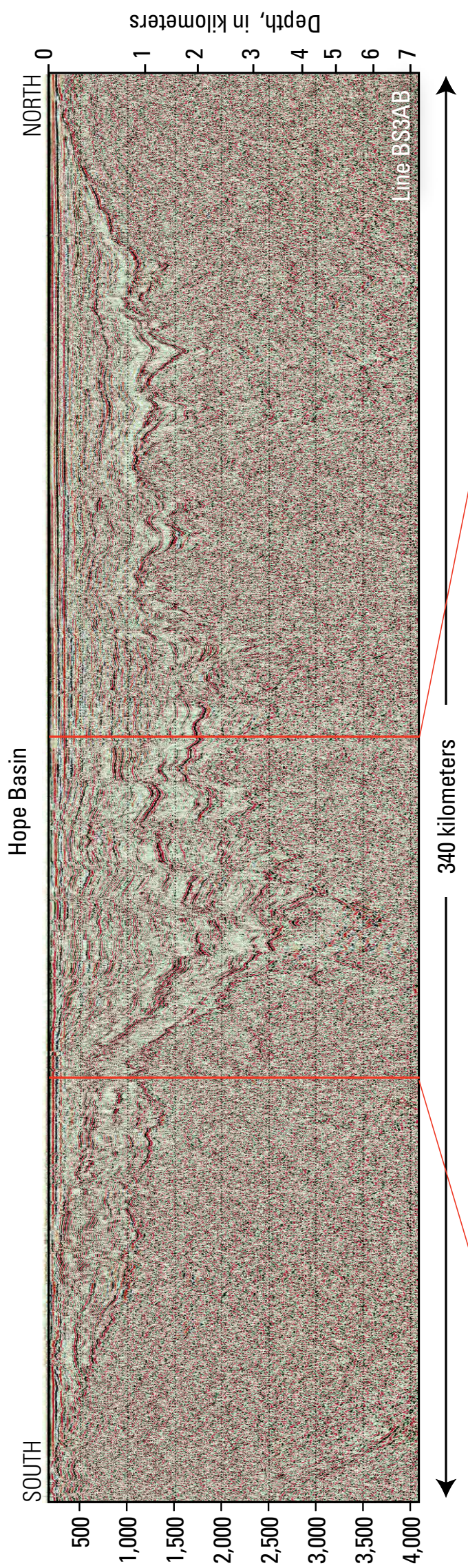

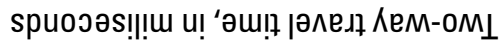

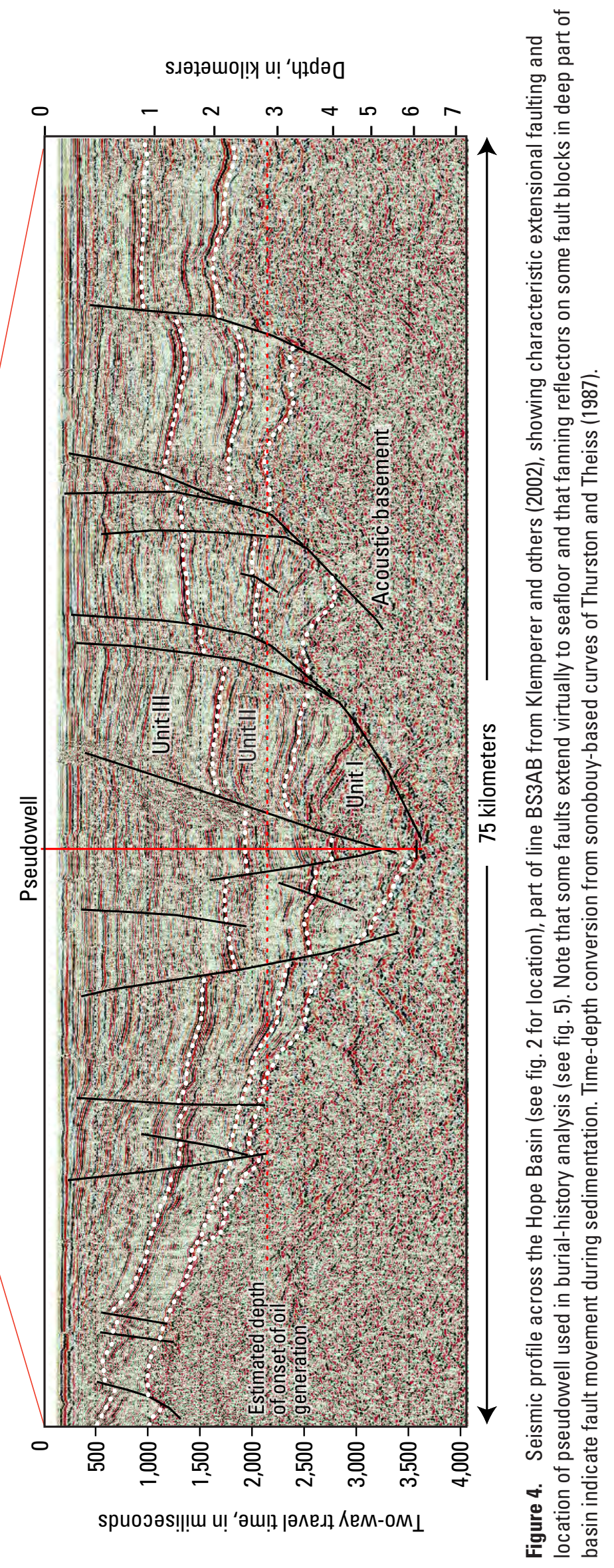



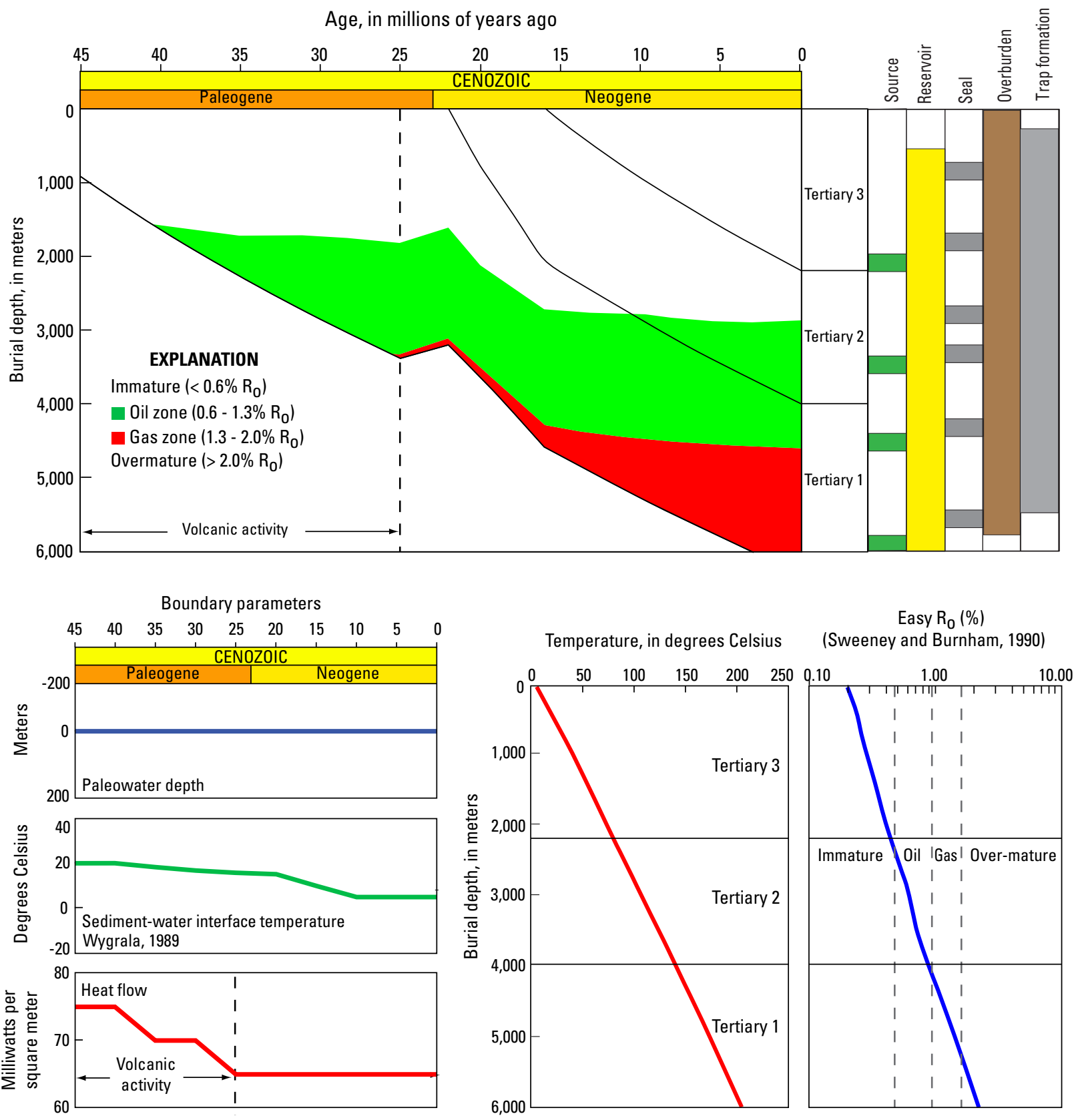

Figure 5. Burial-history diagrams from a pseudowell located in deepest part of the Hope Basin traversed by seismic profile shown in figure 4 (see fig. 2 for location). Sequences and ages used in analysis are derived from exploratory wells in southeastern part of basin, as summarized in figure 3 . Ro, vitrinite reflectance, in percent (\%).

Table 1. Assessment results for the Hope Basin Province (conventional undiscovered resources).

$[\mathrm{BCF}$, billion cubic feet; MMB, million barrels. Results shown are fully risked estimates. For gas fields, all liquids are included in the category of natural-gas liquids (NGL). F95, 95-percent probability of at least the amount tabulated, and so on for F50 and F5. Fractiles are additive under the assumption of perfect positive correlation. AU, assessment unit; N/A, not applicable. Numbers do not exactly add to the totals because totals were calculated by statistical aggregation]

\begin{tabular}{|c|c|c|c|c|c|c|c|c|c|c|c|c|c|c|}
\hline \multirow{2}{*}{$\begin{array}{c}\text { Total } \\
\text { petroleum } \\
\text { systems and } \\
\text { assessment } \\
\text { units }\end{array}$} & \multirow{2}{*}{$\begin{array}{c}\text { AU prob- } \\
\text { ability }\end{array}$} & \multirow{2}{*}{$\begin{array}{l}\text { Field } \\
\text { type }\end{array}$} & \multicolumn{4}{|c|}{ Oil (MMB) } & \multicolumn{4}{|c|}{ Gas (BCF) } & \multicolumn{4}{|c|}{ NGL (MMB) } \\
\hline & & & F95 & F50 & F5 & Mean & F95 & F50 & F5 & Mean & F95 & F50 & F5 & Mean \\
\hline \multicolumn{15}{|c|}{ Assessment results-entire province, Cenozoic composite total petroleum system } \\
\hline \multirow{2}{*}{$\begin{array}{l}\text { Hope Basin } \\
\text { AU }\end{array}$} & \multirow{2}{*}{0.168} & Oil & 0 & 0 & 0 & 3 & 0 & 0 & 0 & 5 & 0 & 0 & 0 & 0 \\
\hline & & Gas & N/A & N/A & N/A & N/A & 0 & 0 & 4,458 & 650 & 0 & 0 & 78 & 11 \\
\hline
\end{tabular}


and maximum oil/gas ratios were set at $0,0.02$, and 0.1 (appendix 1).

Size Distribution.-The median and maximum sizes of an oil field were set to 70 and 300 million barrels of oil (MMBO), and those of a gas field to 500 and 5,000 billion cubic feet of gas (BCFG), respectively.

Province Geologist's Estimated Maximum Field Size.Maximum sizes of oil and gas fields were set to 50 to 100 MMBO and 1,000 to 2,000 BCFG, on the basis of the interpretation that some very large traps are probably present but that maximum accumulation size would be constrained by limited hydrocarbon charge and, possibly, by seal integrity.

Ancillary Properties and Coproduct Ratios relied on the world averages reported by Charpentier and others (2008).

\section{Results}

Probabilistic estimates of volumes of undiscovered, technically recoverable hydrocarbons for the Hope Basin AU are summarized in table 1 . These results include mean estimates of about $3 \mathrm{MMBO}$ of oil and $648 \mathrm{BCFG}$ of nonassociated gas.

\section{Acknowledgments}

We thank Kirk Sherwood, U.S. Minerals Management Service, and Richard W. Saltus, USGS, for their helpful reviews of the manuscript.

\section{References Cited}

Charpentier, R.R., Klett, T.R., and Attanasi, E.D., 2008, Database for assessment unit-scale analogs, exclusive of the United States: U.S. Geological Survey Open-File Report 2007-1404, 61 p. [Available at http://pubs.usgs.gov/ of/2007/1404/].

Decker, J., Robinson, M.S., Clough, J.G., and Lyle, W.M., 1988, Geology and petroleum potential of Hope and Selawik Basins: Alaska Division of Geological and Geophysical Surveys Public-Data File 88-1, 63 p.

Elswick, V.L., and Toro, J., 2003, Seismic interpretation and structural evaluation of the Hope Basin, Alaska [abs.]: Geological Society of America, Annual Meeting, Abstracts with Programs, v. 35, no. 6, p. 28. [Also available at https:// gsa.confex.com/gsa/2003AM/finalprogram/abstract_66247. htm. Poster available at http://www.geo.wvu.edu/ jotoro/ download/download.htm.]
Eittreim, S., Grantz, A., and Whitney, O.T., 1978, Isopach maps of Tertiary sediments, Hope Basin, southern Chukchi Sea, Alaska: U.S. Geological Survey Miscellaneous Field Studies Map MF-906, 1 sheet, scale 1:1,000,000.

Fujita, K., Cook, D.B., Hasegawa, H., Forsyth, D., and Wetmiller, R., 1990, Seismicity and focal mechanisms of the Arctic region and the North American plate boundary in Asia, in Grantz, A., Johnson, L., and Sweeney, J.F., eds., The Arctic Ocean region: Geological Society of America, DNAG, The geology of North America, v. L, p. 79-100.

Grantz, A., May, S.D., and Hart, P.E., 1990, Geology of the Arctic continental margin of Alaska, in Grantz, A., Johnson, L., and Sweeney, J.F., eds., The Arctic Ocean region: Geological Society of America, DNAG, The geology of North America, v. L, p. 257-288.

Grantz, A., Scott, R., Drachev, S.S., and Moore, T.E., 2009, Tectonostratigraphic accumulations of the Arctic Region, $58^{\circ}-64^{\circ}$ to $90^{\circ} \mathrm{N}$, that may be prospective for hydrocarbons: American Association of Petroleum Geologists GIS-UDRIL Open-File Library, 68 p., 4 sheets, scale $1: 4,000,000$.

Haimila, N.E., Kirschner, C.E., Nassichuk, W.W., Ulmichek, G., and Procter, R.M., 1990, Sedimentary basins and petroleum resource potential of the Arctic Ocean region, in Grantz, A., Johnson, L., and Sweeney, J.F., eds., The Arctic Ocean Region: Geological Society of America, DNAG, The geology of North America, v. L, p. 503-538.

Johnsson, M.J., Evans, K.R., and Marshall, H.A., 1999, Thermal maturity of sedimentary rocks in Alaska-Digital Resources: U.S. Geological Survey Digital Data Series DDS-54, CD-ROM [available at http://pubs.usgs.gov/dds/ dds-54/].

Klemperer, S.L., Miller, E.L., Grantz, A., Scholl, D.W., and the Bering-Chukchi Working Group, 2002, Crustal structure of the Bering and Chukchi shelves-Deep seismic reflection profiles across the North American continent between Alaska and Russia, in Miller, E.L., Grantz, A., and Klemperer, S.L., eds., Tectonic evolution of the Bering ShelfChukchi Sea-Arctic Margin and adjacent landmasses: Geological Society of America Special Paper 360, p. 1-24.

Lothamer, R.T., 1994, Early Tertiary wrench faulting in the North Chukchi Basin, Chukchi Sea, Alaska, in Thurston, D.K., and Fujita, K., eds., Proceedings of the first international conference on Arctic margins (1992): U.S. Minerals Management Service OCS Study MMS 94-0040, p. 251-256.

Mazarovich, A.O., and Sokolov, S.Y., 2003, Tectonic subdivision of the Chukchi and East Siberian Seas: Russian Journal of Earth Sciences, v. 5, no. 3, p. 185-202. 
Molenaar, C.M., 1985, Subsurface correlations and depositional history of the Nanushuk Group and related strata, North Slope, Alaska, in Huffman, A.C., Jr., ed., Geology of the Nanushuk Group and related rocks, North Slope, Alaska: U.S. Geological Survey Bulletin 1614, p. 37-59.

Moore, T.E., Dumitru, T.A., Adams, K.E., Witebsky, S.N., and Harris, A.G., 2002, Origin of the Lisburne Hills-Herald Arch-Wrangel Arch structural belt-Stratigraphic, structural, and fission-track evidence from the Cape Lisburne area, northwestern Alaska, in Miller, E.L., Grantz, A., and Klemperer, S.L., eds., Tectonic evolution of the Bering Shelf-Chukchi Sea-Arctic Margin and adjacent landmasses: Geological Society of America Special Paper 360, p. 77-109.

Scholl, D.W., and Stevenson, A.J., 1989, The Aleutian-Bowers-Shirshov arc system, response to deformation of Alaska ("orocline") by subduction-driven impact and escape of crustal masses - Exploration of an idea [abs.]: Eos (American Geophysical Union Transactions), v. 70, no. 43, p. 1307, abstract no. T12B-3.

Shipilov, E.V., 1989, The graben-rift system of the Chukchi Sea: International Geology Review, v. 31, p. 1097-1106.

Sokolov, S.D., Bondarenko, G.Y., Morozov, O.L., Shekhovtsov, V.A., Glotov, S.P., Ganelin, A.V., and KravchenkoBerezhnoy, I.R., 2002, South Anyui suture, northeast Arctic Russian-Facts and problems, in Miller, E.L., Grantz, A., and Klemperer, S.L., eds., Tectonic evolution of the Bering Shelf-Chukchi Sea-Arctic Margin and adjacent landmasses: Geological Society of America Special Paper 360, p. 209-224.

Sweeney, J.J., and Burnham, A.K., 1990, Evaluation of a simple model of vitrinite reflectance based on chemical kinetics: American Association of Petroleum Geologists Bulletin, v. 74, no. 10, p. 1559-1570.

Thurston, D.K., and Theiss, L.A., 1987, Geologic report for the Chukchi Sea planning area, Alaska-Regional geology, petroleum geology, and environmental geology: U.S. Minerals Management Service, OCS Report MMS 87-0046, $193 \mathrm{p}$.
Till, A.B., and Dumoulin, J.A., 1994, Geology of Seward Peninsula and St. Lawrence Island, in Plafker, G., and Berg, H.C., eds., The geology of Alaska: Geological Society of America, DNAG, The geology of North America, v. G-1, p. $141-152$.

Tolson, R.B., 1987, Structure and stratigraphy of the Hope Basin, southern Chukchi Sea, Alaska, in Scholl, D.W., Grantz, A., and Vedder, J.G., eds., Geology and resource potential of the continental margin of western North America and adjacent ocean basins, Beaufort Sea to Baja California: Circum-Pacific Council for Energy and Mineral Resources, p. 59-71.

Troutman, S.M., and Stanley, R.G., 2004, Maps showing sedimentary basins, surface thermal maturity, and indications of petroleum in the Central Alaska Province: U.S. Geological Survey Miscellaneous Field Studies Map MF-2428, 19 p., scale 1:2,500,000. [Also available at http://pubs.usgs.gov/ $\mathrm{mf} / 2003 / 2428 /$.

Warren, T., Sherwood, K.W., Thurston, D.K., Kruglyak, V.F., Zerwick, S.A., Shcherban, O.V., and Grevtsev, A.V., 1995, Petroleum exploration opportunities on the U.S.-Russia Chukchi Sea Continental Shelf in Chung, J.S., Das, B.S., Natvig, B.J., and Olagnon, M., eds., Proceedings of the Fifth International Offshore and Polar Engineering Conference, v. II: Golden, Colo., International Society of Offshore and Polar Engineers, p. 493-500.

Worrall, D.M., 1991, Tectonic history of the Bering Sea and the evolution of Tertiary strike-slip basins of the Bering Shelf: Geological Society of America Special Paper 257, $120 \mathrm{p}$.

Wygrala, B.P., 1989, Integrated study of an oil field in the southern Po Basin, northern Italy: Berichte der Kernforschungsanlage Julich, no. 2313, ISSN 0366-0885, 217 p.

Zerwick, S.A., 1998, Hope Basin assessment province, in Sherwood, K.W., ed., Undiscovered oil and gas resources, Alaska federal offshore, as of January 1995: U.S. Minerals Management Service OCS Monograph MMS 98-0054, p. 217-228. 


\section{Appendix}

Appendix is are available online only, and may be accessed at https://doi.org/10.3133/pp1824D

Appendix 1. Input data for the Hope Basin Assessment Unit 
